\title{
A STUDY OF ECOLOGICAL DEPENDENCE OF HEALTH INDICATORS OF THE CHIL POPULATION IN AGRICULTURAL REGION ON EXAMPLE OF CHERNIHIV REGION
}

\author{
Ponomarenko N.P., Korshun M.M., Garkavyi S.I., Antomonov M.Y.
} ВИВЧЕННЯ ЕКОЛОГГЧНОЇ ЗАЛЕЖНОСТІ ПОКАЗНИКІВ ЗДОРОВ'Я
ДИТЯЧОГО НАСЕЛЕННЯ АГРАРНОГО РЕГОНУ НА ПРИКЛАДІ ЧЕРНГГВЩИНИИ

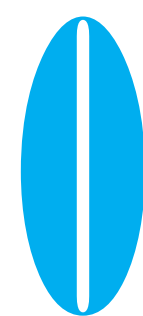

1,2ПОНОМАРЕНКО Н.П., 'КОРШУН М.М., 'ГАРКАВИЙ С.І.,' ${ }^{3}$ АНТОМОНОВ М.Ю.

'Національний медичний університет

ім. О.О. Богомольця, м. Київ ${ }^{2}$ Головне управління Держсанепідслужби у Чернігівській області, м. Чернігів ${ }^{3}$ ДУ "Інститут громадського здоров'я ім. О.М. Марзєєва НАМН України", м. Київ

УДК: 574:312.6-053.2(122)(477.51)

Ключові слова: чинники довкілля, крос-кореляція, здоров'я, дитяче населення, Чернігівська область. днією $з$ найбільш складних проблем гігієни $€$ виявлення хронічного впливу чинників довкілля малої інтенсивності на стан здоров'я населення. Розв'язання цього завдання ускладнюється тим, що у біології та медицині дуже часто спостерігається запізнення відповіді з боку живих організмів на вплив тих чи інших чинників довкілля [1]. У цих випадках традиційні методи вивчення зв'язку між чинниками довкілля та показниками здоров'я населення, зокрема кореляційний аналіз, не завжди дозволяють виявити таку залежність. Тому виникає необхідність оцінки впливу чинників довкілля, що динамічно змінюються, на показники здоров'я населення за умови зсуву часових серій відносно один одного на певний проміжок часу (лаг, $\Delta \mathrm{t})$. У деяких випадках наявність часового лагу є очевидною, але здебільшого для його виявлення і, особливо, визначення його довжини необхідно провести ретельне вивчення динамічних рядів з використанням крос-кореляційного аналізу. Такий підхід дозво- ляє не лише оцінити причиннонаслідковий зв'язок між чинниками навколишнього середовища та показниками здоров'я населення, а й визначити час, за який вплив забруднення довкілля спричинить виникнення порушень здоров'я, тобто знайти значення лагу, за якого рівень забруднення найбільше корелює $з$ рівнем показників здоров'я людини [2]. Зазначене поглибить наше розуміння закономірностей виникнення порушень здоров'я внаслідок несприятливого впливу факторів довкілля, що, у свою чергу, дозволить науково обґрунтувати профілактичні заходи та не допустити зростання екологічно зумовленої патології.

Мета роботи: вивчення причинно-наслідкової залежності між станом довкілля та рівнем показників здоров'я дитячого населення аграрного регіону на прикладі районів Чернігівської області.

Для досягнення мети було необхідно визначити відтермінований зв'язок між станом забруднення питної води, харчових продуктів, атмосферного пові-
ИЗУЧЕНИЕ ЭКОЛОГИЧЕСКОЙ ЗАВИСИМОСТИ

ПОКАЗАТЕЛЕЙ ЗДОРОВЬЯ ДЕТСКОГО

НАСЕЛЕНИЯ АГРАРНОГО РЕГИОНА

НА ПРИМЕРЕ ЧЕРНИГОВЩИНЫ

1,2 Пономаренко Н.П., ' ${ }^{1}$ Коршун М.М.,

${ }^{1}$ Гаркавый С.И., ${ }^{3}$ Антомонов М.Ю.

1 Национальный медицинский университет

им. А.А. Богомольца, г. Киев

${ }^{2}$ Главное управление Госсанэпидслужбы

в Черниговской области, г. Чернигов

${ }^{3}$ ГУ "Институт общественного здоровья

им. А.Н. Марзеева НАМН Украины", г. Киев

Цель работы: выявление причинно-

следственной зависимости между состоянием окружающей среды и показателями здоровья детского населения аграрного региона на примере Черниговской области.

Материалы и методы. Изучена динамическая связь между загрязнением питьевой воды, пищевых продуктов, атмосферного воздуха, почвы и уровнем первичной и общей заболеваемости детей 0-14 лет, мертворождаемости, перинатальной, неонатальной, постнеонатальной, младенческой смертности за 2001-2012 годы. Для реализации цели применен кросскорреляционный анализ с определением коэффициента корреляции $(r)$ и лага $(\Delta t)$, рассчитанного в годах, через который наиболее четко проявляются изменения показателей здоровья детского населения вследствие действия факторов окружающей среды.

Результаты. Установлено, что ведущими факторами, оказывающими отсроченное во времени влияние на состояние здоровья сельского детского населения Черниговщины, являются загрязнение атмосферного воздуха, эпидемическая безопасность пищевых продуктов, гельминтологическое и бактериальное загрязнение почвы, качество питьевой воды (при централизованном водоснабжении - по санитарно-химическим показателям, при децентрализованном по санитарно-химическим и санитарнобактериологическим показателям). Химическое загрязнение почвы, бактериальное загрязнение водопроводной воды, радиационное и химическое загрязнение пищевых продуктов оказывают отсроченное влияние лишь на отдельные показатели состояния здоровья детей.

Ключевые слова: кросс-корреляция, факторы окружающей среды, здоровье, детское население, Черниговская область.

(C) Пономаренко Н.П., Коршун М.М., Гаркавий С.І., Антомонов М.Ю.

СТАTTЯ, 2016. 
тря і ґрунту за 2001-2012 роки та рівнем первинної і загальної захворюваності (захворюваності та поширеності хвороб відповідно) дітей 0-14 років, мертвонароджуваності, перинатальної, неонатальної, постнеонатальної, малюкової смертності; встановити провідні чинники довкілля, що спричиняють виникнення порушень здоров'я за певний проміжок часу їхнього впливу.

Матеріали і методи. Джерелом інформації про рівні первинної та загальної захворюваності, перинатальної, малюкової смертності та мертвонароджуваності за 2001-2012 роки були дані Обласного центру інформаційно-аналітичних технологій та пропаганди здорового способу життя Чернігівської обласної ради. Аналіз здоров'я дітей сільських районів Чернігівщини за зазначеними показниками наведено у роботах $[3,4]$.

Рівні хімічного, бактеріологічного, гельмінтологічного та радіоактивного забруднення питної води за централізованого (водопровідна вода) та децентралізованого (колодязна вода) водопостачання, харчових продуктів, об'єктів довкілля (атмосферного повітря та ґрунту) вивчали за даними статистичної форми № 18 "Звіт про фактори навколишнього середовища, що впливають на стан здоров'я людини" 22 адміністративних районів області (міста державного та обласного підпорядкування не враховували) за досліджуваний період.

Інтегральну оцінку забруднення довкілля проведено за індексом сумарного забруднення (I), визначеного на підставі даних щодо частоти нестандартних проб питної води, харчових продуктів, атмосферного повітря та ґрунту за вказаними вище показниками для кожного району області за методикою, що запропонована Климчук М.А. [5]. Аналогічно розраховано окремо індекси хімічного $\left(\mathrm{I}_{\text {хім. }}\right)$ та сумарного бактеріального і гельмінтологічного (І бак.) забруднення довкілля. Аналіз стану навколишнього середовища сільських районів Чернігівщини за зазначеними показниками наведено у роботах [6, 7].

Для оцінки зв'язку між станом довкілля (інтегральними індексами I, I хім., І бак. та окремими чинниками) і рівнем досліджуваних показників здоров'я дитячого населення побудовано електронну таблицю даних у форматі "Microsoft Office Excel" (2007). На попередньому етапі нами

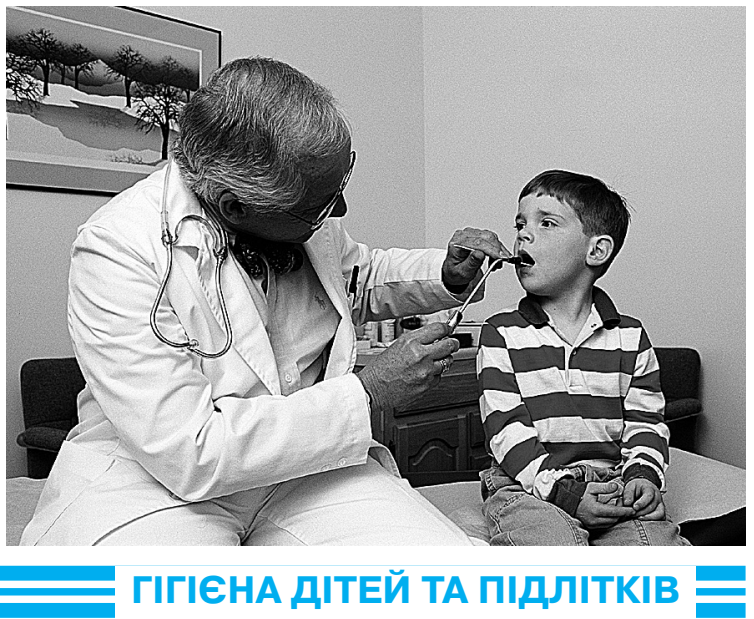

проведено кореляційний аналіз з розрахунком коефіцієнта кореляції Пірсона (r1). Для остаточної реалізації поставленої мети застосовано крос-кореляційний аналіз з визначенням коефіцієнта кореляції (r) та лагу $(\Delta t)$, вимірюваного у роках, через який найбільш чітко проявляються порушення у стані здоров'я внаслідок дії факторів навколишнього середовища. Статистичну обробку проведено за програмою STATISTICA 10.0.

Результати дослідження та їх обговорення. Встановлено позитивний достовірний кореляційний зв'язок між рівнями захворюваності і поширеності усіх хвороб серед дітей 0-14 років та окремими чинниками довкілля: хімічним забрудненням атмосферного повітря $(r=0,16$, $\mathrm{p}<0,05, \Delta \mathrm{t}=8,9$ та $\mathrm{r}=0,16, \mathrm{p}<0,05$, $\Delta \mathrm{t}=12$ відповідно), бактеріальним забрудненням питної води за децентралізованого водопостачання ( $r=0,15, p<0,05, \Delta t=1$ в обох випадках). Також виявлено кореляційний зв'язок між рівнем первинної захворюваності та хімічним забрудненням колодязної води $(r=0,14, p<0,05, \Delta t=1)$ i гельмінтологічним забрудненням ґрунту $(r=0,17, \mathrm{p}<0,05, \Delta \mathrm{t}=1)$.

Зазначимо, що за підсумками кореляційного аналізу між захворюваністю та поширеністю усіх хвороб та хімічним забрудненням атмосферного повітря достовірного зв'язку виявлено не було. Крос-кореляційний аналіз дозволив його виявити та встановити, що шкідливий вплив зазначеного фактора спричиняє виникнення порушень стану здоров'я дітей сільських районів Чернігівщини максимально через 9 (захворюваність) та 12 (поширеність) років, тобто прояви дії цього чинника відтерміновані у часі.

В усіх інших зазначених вище випадках виявлено зв'язок під час проведення кореляційного та крос-кореляційного аналізів, що може бути зумовленим коротким часовим зсувом $(\Delta \mathrm{t}=1)$ між дією цих чинників довкілля та погіршенням показників захворюваності.

Результати вивчення наявності відтермінованого причинно-наслідкового зв'язку між досліджуваними шкідливими чинниками довкілля та показниками захворюваності за окремими класами хвороб (за міжнародною класифікацією хвороб МКХ-10) свідчать про позитивний достовірний кореляційний зв'язок між індексом сумарного забруднення (I) та рівнем первинної і загальної захворюваності на деякі інфекційні та паразитарні хвороби, клас I $(r=0,25, p<0,05, \Delta t=1$ та $r=0,24$, $\mathrm{p}<0,05, \Delta \mathrm{t}=1$ відповідно), хвороби крови та кровотворних органів, клас III $(r=0,19, p<0,05, \Delta t=1$ та $r=0,29, p<0,05, \Delta t=8,11)$, ендокринної системи, розладу харчування та порушення обміну речовин, клас IV ( $\mathrm{r}=0,17, \mathrm{p}<0,05, \Delta \mathrm{t}=1$ та $r=0,19, p<0,05, \Delta t=4)$, нервової системи, клас VI $(r=0,25, p<0,05$, $\Delta \mathrm{t}=3$ та $\mathrm{r}=0,18, \mathrm{p}<0,05, \Delta \mathrm{t}=1,3)$, системи кровообігу, клас IX $(r=0,19, p<0,05, \Delta t=6$ та $r=0,17$, $\mathrm{p}<0,05, \Delta \mathrm{t}=5)$, а також рівнем первинної захворюваності на хвороби кістково-м'язової системи та сполучної тканини, клас XIII $(r=0,15, p<0,05, \Delta t=3)$.

у більшості зазначених вище випадків при кореляційному аналізі також виявлено позитивний достовірний зв'язок, окрім захворюваності на хвороби XIII класу, поширеності хвороб III і IV класів та сумарним забрудненням довкілля, прояв впливу якого на дані класи хвороб відбувається через певний проміжок часу.

Приклад результату крос-коням зв'язку між індексом сумарного забруднення довкілля (I) та рівнем поширеності хвороб крови та кровотворних органів представлено на рисунку, з якого видно, що достовірний позитивний зв'язок спостерігається зі зсувом від 4 до 13 років з максимальним значенням коефіцієнта кореляції 0,29 за 11 років.

Одним із завдань дослідження було визначити провідні чинниреляційного аналізу з визначен- 
ки навколишнього середовища, забруднення якими здійснює найбільш відтермінований у часі вплив на формування рівнів захворюваності за вказаними вище класами хвороб. Результати вивчення наявності зв'язків між забрудненням основних об'єктів довкілля та рівнями захворюваності і поширеності хвороб окремих класів представлено у таблицях 1 i 2.

Встановлено кореляційний зв'язок між первинною і загальною захворюваністю на інфекційні хвороби (клас I) та індексом сумарного бактеріального і гельмінтологічного забруднення довкілля (І бак.) ( $\Delta \mathrm{t}=1$ рік для обох показників захворюваності), бактеріальним забрудненням кожного з досліджуваних об'єктів довкілля (окрім питної води за централізованого водопостачання, яка знезаражується перед подачею до водопровідної мережі) ( $\Delta \mathrm{t}=1$ рік для кожного об'єкта), гельмінтологічним забрудненням ґрунту $(\Delta t=5,7$ рік) (табл. 2).

Кореляційний зв'язок наявний між первинною і загальною захворюваністю на хвороби крови та кровотворних органів (клас III) і хімічним забрудненням харчових продуктів, І бак, бактеріальним та гельмінтологічним забрудненням ґрунту, а також між первинною захворюваністю на хвороби III класу та бактеріальним забрудненням водопровідної води, між поширеністю хвороб III класу та індексом хімічного забруднення довкілля $\left(\mathrm{I}_{\text {хім. }}\right)$, хімічним забрудненням ґрунту і водопровідної води та бактеріальним забрудненням харчових продуктів (табл. 1 і 2).

Кореляційний зв'язок між індексом сумарного забруднення довкілля (I) та рівнем поширеності хвороб крови та кровотворних органів,у тому числі анемій (клас III за MKX-10)

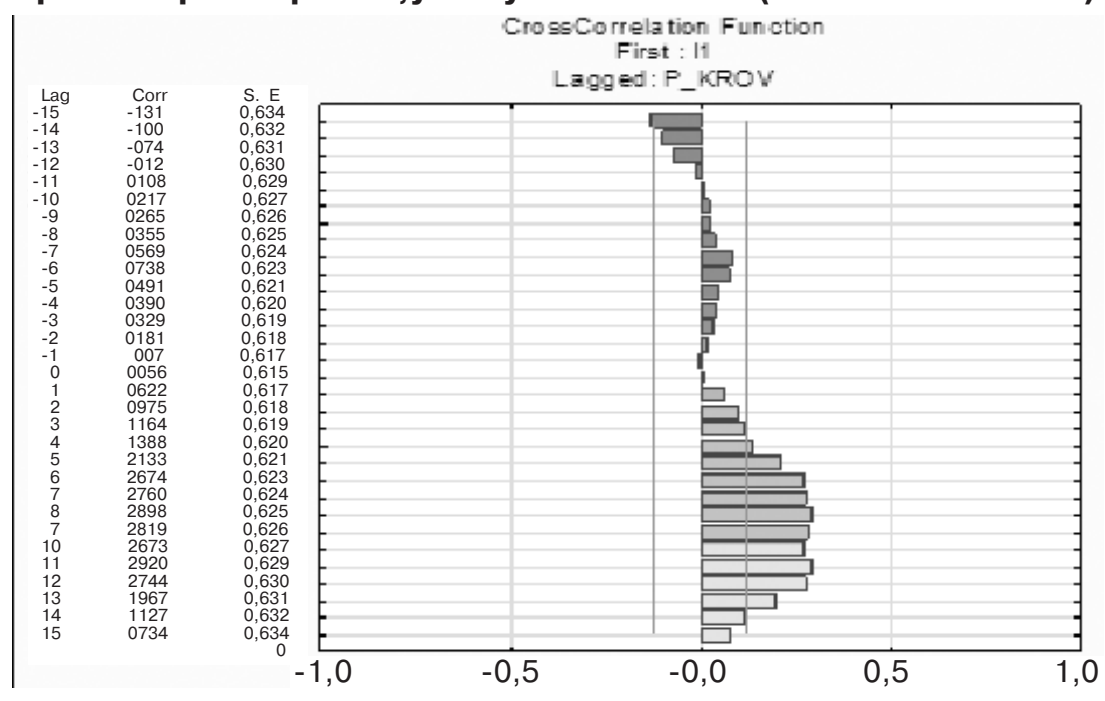

інших класів та сумарним індексом забруднення довкілля (I) позитивні достовірні зв'язки відсутні, проте встановлено відтермінований у часі вплив окремих факторів навколишнього середовища на показники здоров'я (табл. 1 і 2). Так, крос-кореляційний аналіз показав наявність зв'язку між забрудненням об'єктів довкілля та первинною і загальною захворюваністю на хвороби таких класів: новоутвореннями (клас II) та хімічним забрудненням атмосферного повітря і питної води за децентралізованого водопостачання (лише поширеність); хворобами ока та його придаткового апарату (VII) та хімічним забрудненням питної води незалежно від системи водопостачання, бактеріальним забрудненням колодязної води, I хім. (тільки поширеність); хворобами вуха та соскоподібного відростка (VIII) та I хім.' хімічним забрудненням атмосферного повітря, бактеріальним забрудненням продуктів харчування (тільки поширеність); хворобами органів дихання $(\mathrm{X})$ та І бак., гельмінтологічним забрудненням ґрунту, бактеріальним забрудненням колодязної води (лише поширеність); хворобами органів травлення (XI) та бактеріальним забрудненням питної води за децентралізованого та централізованого (лише поширеність) водопостачання, хімічним забрудненням атмосферного повітря; хворобами шкіри та підшкірної клітковини (XII) та І хім., хімічним забрудненням атмосферного повітря, колодязної та водопровідної (тільки поширеність) води, бактеріальним забрудненням продуктів харчування (тільки захворюваність); хворобами сечостатевої системи (XIV) та хімічним забрудненням атмосферного повітря, бактеріальним забрудненням ґрунту (тільки поширеність). Наявний кореляційний зв'язок між поширеністю вроджених вад (XVII) та хімічним забрудненням колодязної води і бактеріальним забрудненням продуктів харчування, а також між первинною захворюваністю на отруєння, травми і деякі інші наслідки дії зовнішніх причин (XIX) та хімічним забрудненням атмосферного повітря, бактеріальним забрудненням питної води за централізованого водопостачання і гельмінтологічним забрудненням ґрунту.

Зауважимо, що статистично значимі залежності 3 часовими зсувами (за результатами крос- 
A STUDY OF ECOLOGICAL DEPENDENCE OF HEALTH INDICATORS OF THE CHILD POPULATION IN AGRICULTURAL REGION ON EXAMPLE OF CHERNIHIV REGION

${ }_{1,2}$ Ponomarenko N.P., , ${ }^{1}$ Korshun M.M., ${ }^{1}$ Garkavyi S. I. , ${ }^{3}$ Antomonov M.Y.

${ }^{1}$ O. Bohomolets National Medical University, Kyiv

${ }^{2}$ Main Department of the State Sanitary

and Epidemiologic Service in Chernihiv region,

Chernihiv

${ }^{3}$ State Institution "O.M. Marzeiev Institute

for Hygiene and Medical Ecology, National Academy of Medical Sciences of Ukraine", Kyiv

Identification of causal relationship between the environment and the level of child health indicators of the agricultural region on an example of Chernihiv region.

Materials and methods. The dynamic relationship between the pollution of drinking water, food, air and soil and level of primary and general morbidity in 0-14 years old children, levels of stillbirth, perinatal, neonatal, post-neonatal, infant mortality in 2001 2012 was studied. A cross-correlation analysis with the determination of cross-correlation coefficient ( $r$ ) and $\log (\Delta t)$, calculated in years, through which most clear changes in indicators of child health due to the action of environmental factors manifest was applied. Results. It was found that the leading factors that have the time-delay impact on the health of the rural child population Chernihiv region are: air pollution, epidemic safety of food, helminthological and bacterial pollution of soil, the quality of drinking water (the sanitary-chemical indicators for centralized water supply; both the sanitary-chemical and sanitary-bacteriological indicators for decentralized water supply).

Chemical pollution of soil, bacterial pollution of tap water, radioactive and chemical pollution of food have a delayed impact only on selected indicators of children's health.

Keywords: cross-correlation, environmental factors, health, child population, Chernihiv region. кореляційного аналізу) виявлено між чинниками довкілля та показниками захворюваності у випадках відсутності між ними позитивного достовірного зв'язку за результатами кореляційного аналізу (табл. 1 і 2). Так, достовірну кореляцію встановлено між I хім. та поширеністю хвороб III класу ( $\Delta \mathrm{t}=8$ рік); хімічним забрудненням атмосферного повітря та первинною і загальною захворю- ваністю на хвороби II ( $\Delta \mathrm{t}=8$ та 7 рік відповідно) та XI ( $\Delta \mathrm{t}=12$ рік для обох показників) класів, первинною захворюваністю на хвороби $\mathrm{XIV}(\Delta \mathrm{t}=8,9$ та 10 рік) та $\mathrm{XIX}(\Delta \mathrm{t}=8$ рік) класів; хімічним забруднен-

Таблиця 1

Зв'язок між хімічним і радіаційним забрудненням об'єктів довкілля та захворюваністю дитячого населення 0-14 років районів Чернігівської області за 2001-2012 роки

\begin{tabular}{|c|c|c|c|c|c|c|c|c|c|c|c|c|c|c|c|c|c|c|c|c|c|}
\hline \multirow{4}{*}{$\mid \begin{array}{ll}0 & 0 \\
0 & 0 \\
\tilde{\sigma} & 0 \\
5 & 0 \\
\underline{0} & x\end{array}$} & \multicolumn{18}{|c|}{ Хімічне забруднення } & \multirow{3}{*}{\multicolumn{3}{|c|}{$\begin{array}{c}\text { Радіаційне } \\
\text { забруднення } \\
\text { харчових } \\
\text { продуктів } \\
\end{array}$}} \\
\hline & \multicolumn{6}{|c|}{ питна вода залежно від водопостачання } & \multirow{2}{*}{\multicolumn{3}{|c|}{$\begin{array}{c}\text { харчові } \\
\text { продукти }\end{array}$}} & \multirow{2}{*}{\multicolumn{3}{|c|}{$\begin{array}{c}\text { атмосферне } \\
\text { повітря }\end{array}$}} & \multirow{2}{*}{\multicolumn{3}{|c|}{ ґрунт }} & \multirow{2}{*}{\multicolumn{3}{|c|}{$\mathrm{I}_{\text {хім. }}$}} & & & \\
\hline & \multicolumn{3}{|c|}{ централізоване } & \multicolumn{3}{|c|}{ децентралізоване } & & & & & & & & & & & & & & & \\
\hline & $r_{1}$ & $r$ & $\Delta \mathrm{t}$ & $r_{1}$ & $r$ & $\Delta \mathrm{t}$ & $r_{1}$ & $r$ & $\Delta \mathrm{t}$ & $r_{1}$ & $r$ & $\Delta \mathrm{t}$ & $r_{1}$ & $r$ & $\Delta \mathrm{t}$ & $r_{1}$ & $r$ & $\Delta \mathrm{t}$ & $r_{1}$ & $r$ & $\Delta \mathrm{t}$ \\
\hline \multicolumn{22}{|c|}{ Захворюваність } \\
\hline II & - & - & - & - & - & - & - & - & - & - & 0,17 & 8 & - & - & - & - & - & - & - & - & - \\
\hline III & - & - & - & - & - & - & 0,27 & 0,14 & 1 & 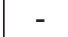 & 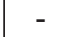 & 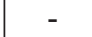 & 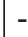 & - & 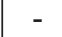 & - & - & - & - & - & - \\
\hline IV & 0,19 & 0,22 & 1 & - & - & - & - & - & - & - & - & - & 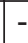 & - & 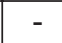 & - & - & - & 0,29 & 0,14 & 11 \\
\hline VI & 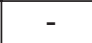 & 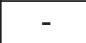 & - & - & - & - & - & 0,19 & 2 & 0,14 & 0,17 & 12,14 & - & - & - & - & - & - & - & - & - \\
\hline VII & 0,23 & 0,21 & 1,2 & 0,28 & 0,30 & 1 & - & - & - & - & - & - & - & - & - & - & - & - & - & - & - \\
\hline VIII & - & - & - & - & - & - & - & - & - & 0,39 & 0,44 & $1-3$ & - & - & - & 0,25 & 0,25 & 2 & - & - & - \\
\hline $\mathrm{XI}$ & - & - & - & - & - & - & - & - & - & - & 0,32 & 12 & - & - & - & - & - & - & - & - & - \\
\hline XII & - & - & - & 0,13 & 0,14 & 1 & - & - & - & 0,23 & 0,25 & 8 & ${ }^{-}$ & - & - & 0,14 & 0,15 & 2,3 & - & - & - \\
\hline XIII & 0,53 & 0,49 & 1 & - & - & - & - & - & - & 0,22 & 0,22 & 9 & - & 0,21 & 2 & 0,28 & 0,29 & 1 & - & - & - \\
\hline XIV & - & - & - & - & - & - & - & - & - & - & 0,21 & $8,9,10$ & - & - & - & - & - & - & - & - & - \\
\hline XIX & - & - & - & - & - & - & - & - & - & - & 0,25 & 8 & $1-$ & - & - & - & - & - & - & - & - \\
\hline \multicolumn{22}{|c|}{ Поширеність хвороб } \\
\hline II & - & - & - & - & 0,17 & 9 & - & - & - & - & 0,22 & 7 & & - & - & - & - & - & - & - & - \\
\hline III & - & 0,14 & 8,9 & - & - & - & - & 0,18 & 12 & - & - & - & - & 0,15 & 9,11 & - & 0,23 & 8 & - & - & - \\
\hline $\mathrm{VI}$ & - & - & - & - & - & - & - & - & - & 0,24 & 0,24 & 8,12 & - & - & - & - & - & - & - & - & - \\
\hline VII & 0,21 & 0,18 & 1 & 0,18 & 0,22 & 1 & - & - & - & - & - & - & - & - & - & 0,17 & 0,17 & 2 & - & - & - \\
\hline VIII & - & - & - & - & - & - & - & - & - & 0,41 & 0,45 & $1,2,3$ & - & - & - & 0,24 & 0,25 & 2 & - & - & - \\
\hline $\mathrm{XI}$ & - & - & 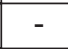 & - & - & - & - & - & - & - & 0,26 & 12 & 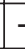 & - & - & - & - & - & - & - & - \\
\hline XII & 0,19 & 0,15 & 1 & 0,16 & 0,16 & 1 & - & - & - & 0,20 & 0,19 & 8 & - & - & - & 0,17 & 0,17 & 2 & - & - & - \\
\hline XIII & 0,43 & 0,37 & 1 & - & - & - & - & - & - & 0,13 & 0,22 & 12 & - & - & - & - & - & - & - & - & - \\
\hline XIV & - & - & - & - & - & - & - & - & - & 0,15 & 0,19 & 13 & 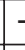 & - & - & - & - & - & - & - & - \\
\hline XVII & - & - & - & - & 0,15 & 11 & - & - & - & - & - & - & 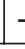 & - & - & - & - & - & - & - & - \\
\hline
\end{tabular}

Примітки до таблиць 1 і 2: $r_{1}$ - коефіцієнт кореляційного аналізу; $r$ - максимальний коефіцієнт кроскореляційного аналізу; $\Delta t$ - значення року, лаг; "-" - достовірний кореляційний зв'язок відсутній. 
ням питної води за централізованого водопостачання та поширеністю хвороб III класу $(\Delta \mathrm{t}=8,9$ рік), питної води за децентралізованого водопостачання та поширеністю хвороб II ( $\Delta \mathrm{t}=9$ рік) і XVII ( $\Delta t=11$ рік) класів; хімічним забрудненням продуктів харчування та первинною захворюваністю на хвороби $\mathrm{VI}$ класу $(\Delta \mathrm{t}=2$ рік), поширеністю хвороб III класу $(\Delta t=12$ рік); хімічним забрудненням ґрунту та первинною захворюваністю на хвороби XIII класу $(\Delta t=2$ рік), поширеністю хвороб III класу ( $\Delta t=9,11$ рік). Тобто за допомогою крос-кореляційного аналізу доведено відтермінований у часі вплив хімічних чинників довкілля на показники захворюваності дітей сільських районів Чернігівщини на новоутворення, хвороби крови та кровотворних органів, нервової системи, органів травлення, сечостатевої та кістково-м'язової систем і сполучної тканини, вроджені вади розвитку, травми, отруєння та через деякі зовнішні причини.

Також за результатами кроскореляційного аналізу відтермінований причинно-наслідковий зв'язок наявний за відсутності зв'язку при кореляційному аналізі між бактеріальним забрудненням води питної централізо- ваного водопостачання та первинною захворюваністю на хвороби III, VI класів; продуктів харчування та захворюваністю на хвороби VI класу, поширеністю хвороб III, VIII, XVIII класів; гельмінтологічним забрудненням ґрунту та первинною захворюваністю на хвороби XIX класу.

Зазначимо, що за підсумками крос-кореляційного аналізу позитивного достовірного зв'язку не виявлено між жодним з досліджуваних факторів довкілля та первинною і загальною захворюваністю на хвороби системи кровообігу (IX клас), а також між хімічним і радіаційним чинниками та первинною і загальною захворюваністю на деякі інФекційні та паразитарні хвороби (I), хвороби органів дихання (X), поширеністю хвороб ендокринної системи (IV), захворюваністю на вроджені вади (XVII); між жодним з досліджуваних бактеріологічних і гельмінтологічним факторами та первинною і загальною захворюваністю на новоутворення (II), первинною захворюваністю на хвороби ока та його придаткового апарату (VII), вуха та соскоподібного відростка (VIII), органів сечостатевої системи (XIV), вродженими вадами розвитку (XVII), поширеністю хвороб ендокринної системи, розладу харчування та порушення обміну речовин (IV), шкіри та підшкірної клітковини (XII) (табл. 1, 2).

Результати дослідження показують наявність відтермінованого у часі впливу однакових забруднюючих факторів на формування рівнів первинної і загальної захворюваності на хвороби певних класів: I клас - бактеріальне забруднення всіх досліджуваних об'єктів довкілля (окрім води питної за централізованого водопостачання) та гельмінтологічне забруднення ґрунту; II, VI, VIII, XIV - хімічне забруднення атмосферного повітря; III - хімічне забруднення продуктів харчування, бактеріальне та гельмінтологічне забруднення ґрунту; VII - хімічне забруднення води питної незалежно від системи водопостачання; X - гельмінтологічне забруднення ґрунту; XI - бактеріальне забруднення колодязної води та хімічне забруднення атмосферного повітря; XII - хімічне забруднення атмосферного повітря і води питної за децентралізованого водопостачання; XIII - xiмічне забруднення водопровідної води та атмосферного повітря.

Проведений крос-кореляційний аналіз впливу стану довкілля районів Чернігівщини на рівні перинатальної смертності, мер-

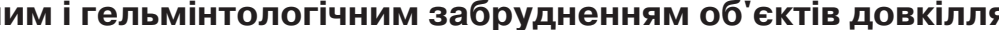
та захворюваністю дитячого населення 0-14 років районів Чернігівської області за 2001-2012 роки

\begin{tabular}{|c|c|c|c|c|c|c|c|c|c|c|c|c|c|c|c|c|c|c|}
\hline \multirow{4}{*}{$\begin{array}{ll}0 & 0 \\
0 & 0 \\
5 & 0 \\
\underline{0} \\
\end{array}$} & \multicolumn{12}{|c|}{ Бактеріологічне забруднення } & \multirow{3}{*}{\multicolumn{3}{|c|}{$\begin{array}{c}\text { Гельмінтологічне } \\
\text { забруднення } \\
\text { ґрунт }\end{array}$}} & \multicolumn{3}{|c|}{ І бак. } \\
\hline & \multicolumn{6}{|c|}{ вода питна залежно від водопостачання } & \multirow{2}{*}{\multicolumn{3}{|c|}{$\begin{array}{c}\text { харчові } \\
\text { продукти }\end{array}$}} & \multirow{2}{*}{\multicolumn{3}{|c|}{ ґрунт }} & & & & & & \\
\hline & \multicolumn{3}{|c|}{ централізоване } & \multicolumn{3}{|c|}{ децентралізоване } & & & & & & & & & & & & \\
\hline & $r_{1}$ & $r$ & $\Delta \mathrm{t}$ & $r_{1}$ & $r$ & $\Delta \mathrm{t}$ & $r_{1}$ & $r$ & $\Delta \mathrm{t}$ & $r_{1}$ & $r$ & $\Delta \mathrm{t}$ & $r_{1}$ & $r$ & $\Delta \mathrm{t}$ & $r_{1}$ & $r$ & $\Delta \mathrm{t}$ \\
\hline \multicolumn{19}{|c|}{ Захворюваність } \\
\hline I & - & - & - & 0,22 & 0,20 & 1 & 0,17 & 0,16 & 1 & 0,18 & 0,16 & 1 & 0,15 & 0,22 & 5,7 & 0,25 & 0,26 & 1 \\
\hline III & - & 0,16 & 12 & - & - & - & - & - & - & 0,27 & 0,25 & 1,5 & 0,24 & 0,26 & 1,2 & 0,26 & 0,29 & 1 \\
\hline IV & - & - & - & - & - & - & 0,30 & 0,18 & 1 & - & - & - & - & - & - & - & - & - \\
\hline $\mathrm{VI}$ & - & 0,14 & 2 & - & - & - & - & 0,14 & 1 & - & - & - & - & - & - & - & - & - \\
\hline$X$ & - & - & - & - & - & - & - & - & - & - & - & - & 0,25 & 0,23 & 1 & 0,19 & 0,16 & 1 \\
\hline $\mathrm{XI}$ & - & - & - & 0,16 & 0,16 & 1 & - & - & - & - & - & - & - & - & - & - & - & - \\
\hline XII & - & - & - & - & - & - & 0,12 & 0,14 & 2 & - & - & - & - & - & - & - & - & - \\
\hline $\mathrm{XIX}$ & 0,20 & 0,14 & 1 & - & - & - & - & - & - & - & - & - & - & 0,14 & $11-15$ & - & - & - \\
\hline \multicolumn{19}{|c|}{ Поширеність хвороб } \\
\hline $\mathrm{I}$ & - & - & - & 0,19 & 0,17 & 1 & 0,16 & 0,14 & 1 & 0,18 & 0,17 & 1 & 0,15 & 0,22 & 5,7 & 0,24 & 0,26 & 1 \\
\hline III & - & - & - & - & - & - & - & 0,16 & 6 & 0,18 & 0,38 & 10 & 0,12 & 0,24 & 11 & 0,11 & 0,33 & 8-10 \\
\hline $\mathrm{VI}$ & - & - & - & - & - & - & - & - & - & - & - & - & 0,15 & 0,15 & $1,4,5$ & 0,15 & 0,16 & 1 \\
\hline VII & - & - & - & 0,22 & 0,23 & 1 & - & - & - & - & - & - & - & - & - & - & - & - \\
\hline VIII & - & - & - & - & - & - & - & 0,16 & 2 & - & - & - & - & - & - & - & - & - \\
\hline$X$ & - & - & - & 0,18 & 0,14 & 1 & - & - & - & - & - & - & 0,26 & 0,25 & 1 & 0,19 & 0,17 & 1 \\
\hline $\mathrm{XI}$ & 0,23 & 0,15 & 1 & 0,20 & 0,15 & 1 & - & - & - & - & - & - & - & - & - & - & - & - \\
\hline XIV & - & - & - & - & - & - & - & - & - & 0,18 & 0,15 & 1 & - & - & - & - & - & - \\
\hline XVII & - & - & - & - & - & - & - & 0,14 & 5 & - & - & - & - & - & - & - & - & - \\
\hline
\end{tabular}


твонароджуваності, смертності дітей до 1 року за 2001-2012 роки показав наявність позитивного достовірного зв'язку між показниками, де був відсутній простий кореляційний зв'язок: сумарним індексом забруднення (I) і рівнем неонатальної смертності $(r=0,20, p<0,05, \Delta t=8)$, xiмічним забрудненням питної води за децентралізованого водопостачання та рівнем малюкової смертності $(\mathrm{r}=0,17$, $\mathrm{p}<0,05, \Delta \mathrm{t}=2$ ), хімічним забрудненням харчових продуктів та рівнем перинатальної смертності $(r=0,14, p<0,05, \Delta t=6)$, радіаційним забрудненням харчових продуктів, продовольчої сировини та рівнем перинатальної і постнеонатальної смертності $(r=0,16, p<0,05, \Delta t=1 ; \quad r=0,14$, $\mathrm{p}<0,05, \Delta t=7$ відповідно). За результатами кореляційного і крос-кореляційного аналізів спостерігається достовірний зв'язок між радіаційним забрудненням харчових продуктів, продовольчої сировини та рівнем мертвонароджуваності $(r=0,22, p<0,05, \Delta \geq t=1)$

\section{Висновки}

1. Крос-кореляційний аналіз дає змогу встановити причиннонаслідкові зв'язки між досліджуваними показниками та кількісно демонструє відтерміноване часове виникнення (лаг, $\Delta \mathrm{t})$ порушень здоров'я внаслідок впливу шкідливих чинників довкілля.

2. Доведено наявність кореляційного зв'язку між сумарним індексом забруднення довкілля (I) у районах Чернігівської області за 2001-2012 роки та рівнями первинної і загальної захворюваності дітей 0-14 років на деякі інфекційні та паразитарні хвороби (клас I), хвороби крови та кровотворних органів, у т.ч. анемії (III), ендокринної системи, розладу харчування та порушення обміну речовин (IV), нервової системи (VI), системи кровообігу (IX), а також з рівнем первинної захворюваності на хвороби кістковом'язової системи та сполучної тканини (XIII).

3. Встановлено провідні фактори довкілля, які чинять відтермінований у часі вплив на рівні первинної та загальної захворюваності дитячого населення загалом (хімічне забруднення атмосферного повітря, бактеріальне забруднення питної води за децентралізованого водопостачання) та на рівні показників захворюваності за окремими класами хвороб.

4. Виявлено причинно-наслідкову залежність між чинниками довкілля та рівнями перинатальної смертності, мертвонароджуваності, смертності дітей до 1 року. Зокрема, встановлено позитивний достовірний зв'язок між сумарним індексом забруднення (I) та рівнем неонатальної смертності, хімічним забрудненням питної води за децентралізованого водопостачання та рівнем малюкової смертності, хімічним забрудненням харчових продуктів та рівнем перинатальної смертності, радіаційним забрудненням харчових продуктів, продовольчої сировини та рівнем перинатальної, постнеонатальної смертності і мертвонароджуваності.

5. Визначено, що провідними чинниками, які здійснюють відтермінований у часі вплив на стан здоров'я сільського дитячого населення Чернігівської області, $є$ якість атмосферного повітря, епідемічна безпека продуктів харчування, гельмінтологічне та бактеріальне забруднення ґрунту, якість питної води (за централізованого водопостачання - за санітарнохімічними показниками, за децентралізованого - за санітарно-хімічними та санітарно-бактеріологічними показниками). Хімічне забруднення ґрунту, бактеріальне забруднення водопровідної води, а також радіаційне та хімічне забруднення харчових продуктів здійснюють відтермінований вплив лише на окремі показники здоров'я підростаючого покоління.

Результати проведеного дослідження нададуть змогу обґрунтувати профілактичні рекомендації з поліпшення стану довкілля та здоров'я дитячого контингенту районів Чернігівщини, враховуючи відтерміновану причинно-наслідкову залежність між ними.

$$
\text { ЛІТЕРАТУРА }
$$

1. Івашків Л.Я. Часова організація біоелектричних і метаболічних процесів у ранньому ембріогенезі в'юна та шпорцевої жаби: автореф. дис.: спец. 03.00.02 "Біофізика" / Л.Я. Івашків. - Л., 2003. - 20 с.

2. Розенберг Г.С. Экологическое прогнозирование (Функциональные предикторы временных рядов) [Электронный ресурс] / Г.С. Розенберг, В.К. Шитиков, П.Т. Брусиловский. - Тольятти, 1994. - 182 с. Режим доступа: http:// www.ievbras.ru/ecostat/Kiril/Library/Book2/Content412/ Content412.htm

3. Пономаренко Н.П. Динаміка захворюваності дитячого насе- лення Чернігівщини // Гігієна населених місць. - 2012. Вип. 60. - С. 93-98.

4. Пономаренко Н.П. Стан малюкової смертності у Чернігівській області / Н.П. Пономаренко, С.І. Гаркавий, М.М. Коршун // Медичні перспективи. - 2013. - T. XVIII, № 3. - C. 134-140.

5. Климчук М.А. Гігієнічна оцінка навколишнього середовища сільських районів Львівської області та його вплив на стан здоров'я населення: автореф. дис.: спец. 14.02.01 "Гігієна" / М.А. Климчук. - К., 2007. - 20 с.

6. Пономаренко Н.П. Оцінка якості господарсько-питного водопостачання районів Чернігівської області / Н.П. Пономаренко, М.М. Коршун // Актуальні проблеми сучасної медицини: Вісник Української медичної академії. - 2014. - Т. 14, вип. 2 (46). - C. 37-43.

7. Пономаренко Н.П. Аналіз забруднення довкілля районів Чернігівської області за період 20012012 років / Н.П. Пономаренко // Науковий огляд. - 2015. Вип. 4 (14). - С. 100-106.

\section{REFERENCES}

1. Ivashkiv L. la. Chasova orhanizatsiia bioelektrychnykh i metabolichnykh protsesiv u rannomu embriohenezi viuna: avtoref. dys. [Temporary organization of bioelectric and metabolic processes during the early embryogenesis of loach Misgurnus fossilis L. and frog Xenopus laevis D.]. Lviv; 2003: 20 p. (in Ukrainian).

2. Rozenberh H.S., Shytykov V.K., Brusilovskyj P.T. Rezhym dostupa: http://www.ievbras.ru/ecostat/Kiril/Library/Book2/Content 412/Content412.htm

3. Ponomarenko N.P. Hihiena naselenykh mists [Hygiene of Settlements]: zb. nauk. prats. Kyiv; 2012; 60: 93-98 (in Ukrainian).

4. Ponomarenko N.P. Harkavyi S.I., Korshun M.M. Medychni perspektyvy. 2013; XVIII, 3: 134140 (in Ukrainian)

5. Klymchuk M.A. Hihienichna otsinka navkolyshnoho seredovyshha silskykh raioniv Lvivskoi oblasti ta ioho vplyv na stan zdorovia naselennia: avtoref. dys. [Hygienic evaluation of districts environment of the Lvov region and his influence on the health of population]. Kyiv; 2007: 20 p. (in Ukrainian).

6. Ponomarenko N.P., Korshun M.M. Aktualni problemy suchasnoi medytsyny: Visnyk Ukrainskoi medychnoi akademii. 2014; 14, 2 (46): 37-43.

7. Ponomarenko N.P. Naukovyi ohliad. 2015; 4 (14): 100-106.

Надійшла до редакції 07.11.2015 